\title{
Growth Performance of Rabbits Fed Diets Containing Different Levels of Energy and Mixture of Some Medicinal Plants
}

\author{
H. A. A. Omer \\ Animal Production Department, National Research Centre, Dokki, Giza, Egypt \\ Tel: 20-11-408-9312 E-mail: hamedomer2000@yahoo.com \\ Sh. A. M. Ibrahim (Corresponding author) \\ Animal Production Department, National Research Centre, Dokki, Giza, Egypt \\ Tel: 20-10-169-4188Ｅ-mail: shawki_nrc@yahoo.com \\ A. A. Abedo \\ Animal Production Department, National Research Centre, Dokki, Giza, Egypt \\ Tel: 20-11-237-3380Ｅ-mail: abedoaa@yahoo.com \\ F. A. F. Ali \\ Animal Production Department, National Research Centre, Dokki, Giza, Egypt \\ Tel: 20-10-652-7044 E-mail:mf_ahmed@live.com
}

Received: April 29, 2011

doi:10.5539/jas.v4n2p201
Accepted: May 12, $2011 \quad$ Online Published: December 21, 2011

URL: http://dx.doi.org/10.5539/jas.v4n2p201

\begin{abstract}
A total number of 48 male growing New Zealand rabbits were used to study the effect of two different levels of ration energy supplemented with mixture of Lupinus albus L, Trigonella foenum-graecum L and Cassia senna $L$ as feed additives. Rabbits were classified into four equal groups $\left(\mathrm{G}_{1}-\mathrm{G}_{4}\right)$. The $1^{\text {st }}$ and $3^{\text {rd }}$ groups received basal ration with $100 \%$ and $90 \%$ energy requirement and served as first and second control respectively. The $2^{\text {nd }}$ and the $4^{\text {th }}$ groups received basal ration with $100 \%$ and $90 \%$ energy requirement supplemented with mixture at the level of $1.5 \%$, respectively. The results showed that decreasing energy requirements level by $10 \%$ in rabbit diets significantly $(\mathrm{P}<0.05)$ increased the digestibility coefficients of DM, OM, CP and NFE \& DCP values. The $90 \%$ energy level insignificant increased $(\mathrm{P}>0.05) \mathrm{CF}$ and $\mathrm{EE}$ digestibility coefficients and TDN value. The $90 \%$ energy requirement with $1.5 \%$ additives mixture $\left(\mathrm{G}_{4}\right)$ recorded the best digestibility coefficients of DM, OM, $\mathrm{CP}, \mathrm{CF}, \mathrm{EE}, \mathrm{NFE}$ and nutritive values of TDN and DCP.

The $90 \%$ energy level significantly $(\mathrm{P}<0.05$ ) improved feed conversion (g intake /g gain) of DM, CP, DCP, TDN and $\mathrm{DE}$, respectively compared to control. Adding mixture at $1.5 \%$ level significantly $(\mathrm{P}<0.05)$ improved feed conversion (g intake /g gain) of DM, CP, DCP, TDN and DE, respectively compared to control. The $90 \%$ energy with $1.5 \%$ additives mixture $\left(\mathrm{G}_{4}\right)$ recorded the best values of final body weight, body weight gain, and average daily gain as well as feed conversion.

Additives mixture at $1.5 \%$ level significantly $(\mathrm{P}>0.05)$ increased the total inedible offal's (weight and $\%$ of $\mathrm{SW}$ ) and Dm contents of the 9,10 and $11^{\text {th }}$ ribs. The $90 \%$ energy level with $1.5 \%$ additives mixture $\left(\mathrm{G}_{4}\right)$ diet recorded the highest value of relative economic efficiency (145.1\%) and the lowest value of feed cost/ $\mathrm{kg}$ live body weight (3.97 LE).

It can be concluded that this mixture of medicinal plants can be considered as growth promoter that is effective for improving the utilization of low energy diet by lowering circulating glucose levels through enhancing insulin sensitivity.
\end{abstract}

Keywords: Medicinal plants, Rabbits, Growth performance, Digestibility, Carcass characteristics, Economic evaluation 


\section{Introduction}

Recently use of some herbal medicines, have been considered as an alternative for therapeutic usage or to evaluate the hypoglycemic and hypolipidemic effects (Kassaian et al., 2009). Protein and fiber derived from lupin kernel significantly lower influences energy intake acutely (Lee et al., 2006). Fenugreek fiber significantly increased satiety and reduced energy intake (Mathern et al., 2009).

Lupinus albus L. used is the dried sweet white lupine seeds belonging to the leguminosae family. Lupin (Lupinus spp.) seed improve the livestock production efficiency (Van Barneveld, 1999). Lupin had a good nutritional quality; alpha-galactoside-free lupin that can be used as an excellent dietary source for the preparation of dietetic products (Porres et al., 2006). Exogenous enzyme products could lead to lupin non-starch polysaccharides being used as an energy source for poultry (Hughes et al., 2000 and Sami et al., 2010).

Trigonella foenum graecum $L$, used is the dried fenugreek seeds belonging to the leguminosae family. Fenugreek has a long history of medical uses in folklore medicine, and has been used for numerous indications, including labor induction, aiding digestion, and as a general tonic to improve metabolism and health (Basch et al., 2003). Preliminary animal and human trials suggest possible hypoglycemic and antihyperlipidemic properties of oral fenugreek seed powder (Basch et al., 2003). Fenugreek is traditionally used to treat the diabetes disorders (Raju et al., 2004).

Cassia senna $L$. used is the dried senna leaves belonging to the leguminosae family. Cassia senna L. used for thereby decreasing the likelihood of adverse effects and for relax the intestines (Müllera and Basedow, 2006) due to a metabolic effect involving energy production (Nadal et al., 2003).

Low dietary energy requirements may cause imbalance in the body metabolism and growth performance. The hypothesis that if any component lowered circulating glucose levels indicating that this component is enhancing insulin sensitivity as well as improving the utilization of low energy diet. Some essential oils lowered circulating glucose levels and systolic blood pressure, suggesting that these natural products are enhancing insulin sensitivity (Talpur, 2005). Lupins have unique carbohydrate properties characterized by high levels of raffinose oligosaccharides, all of which can lower the utilization of energy (Van Barneveld, 1999). Lupin kernel flour significantly lower influences energy intake acutely (Lee et al., 2006). Fenugreek seeds exert antidiabetic effects mediated through enhancement of peripheral insulin action (Hannan et al., 2007), with possible hypoglycemic and antihyperlipidemic properties of oral fenugreek seed powder (Basch et al., 2003) as well as fenugreek fiber significantly increased satiety and reduced energy intake (Mathern et al., 2009). Carbohydrates in senna include $2 \%$ polysaccharides and approximately $10 \%$ mucilage consisting of galactose, arabinose, rhamnose, and galacturonic acid (Bisset et al., 1994). Other carbohydrates in senna include mannose, fructose, glucose, pinitol, and sucrose (Newall et al., 1996).

This work aimed to evaluate the efficacy of lupine, fenugreek and senna as feed additives in improving the utilization of low energy rabbit diet as well as growth performance.

\section{Materials and Methods}

A total number of 48 male New Zealand White rabbits aged 5 weeks with an average body weight of $796 \pm$ $19.19 \mathrm{~g}$, were divided into four equal groups. The basal experimental diet was formulated and pelleted to cover the nutrient requirements of rabbits as a basal diet according to NRC (1977) as shown in (Table 1). Additives mixture used in this study are composed of Lupinus albus L, Trigonella foenum-graecum L and Cassia senna L. at ratio of (1:1: 0.25$)$, respectively. The feeding period was extended for 56 days, and the experimental groups were classified as follow:

Group 1 basal diet with $100 \%$ energy requirement and served as control $\left(\mathrm{G}_{1}\right)$,

Group 2 basal diet with $100 \%$ energy requirement $+1.5 \%$ additives mixture $\left(\mathrm{G}_{2}\right)$,

Group 3 basal diet with $90 \%$ energy requirement and served as control $\left(\mathrm{G}_{3}\right)$ and

Group 4 basal diet with $90 \%$ energy requirement $+1.5 \%$ additives mixture $\left(\mathrm{G}_{4}\right)$.

Rabbits individually housed in galvanized wire cages $(30 \times 35 \times 40 \mathrm{~cm})$. Stainless steel nipples for drinking and feeders allowing recording individual feed intake for each rabbit were supplied for each cage. Feed and water were offered ad libitum. Rabbits of all groups were kept under the same managerial conditions and were individually weighed, and feed consumption was individually recorded weekly during the experimental period.

At the end of the experimental period, six rabbits from each treatment were used in digestibility trials over period of 7 days to determine the nutrient digestibility coefficients and nutritive values of the tested diets. Feces were daily collected quantitatively. Feed intake of experimental rations and weight of feces were daily recorded. Representative samples of feces was dried at $60^{\circ} \mathrm{C}$ for $48 \mathrm{hrs}$, ground and stored for later chemical analysis. 
Six representative rabbits from each treatment were randomly chosen and fasted for 12 hours before slaughtering according to Blasco et al. (1993) to determine the carcass measurements. Edible offal's (Giblets) included heart, liver, testes and kidneys were removed and individually weighed. Full and empty weights of digestive tract were recorded and digestive tract contents were calculated by differences between full and empty digestive tract. Weights of giblets and external offal's were calculated as percentages of slaughter weight (SW). Hot carcass was weighed and divided into fore, middle and hind parts. The 9, 10 and $11^{\text {th }}$ ribs were frozen in polyethylene bags for later chemical analysis. The best ribs of samples were dried at $60 \mathrm{C}^{\circ}$ for $24 \mathrm{hrs}$. The air-dried samples were analyzed for DM, EE and ash according to the A.O.A.C. (2000) methods, while CP percentage was determined by difference as recommended by O'Mary et al. (1979).

Chemical analysis of experimental rations and feces were analyzed according to A.O.A.C (2000) methods. Neutral detergent fiber (NDF), acid detergent fiber (ADF) and acid detergent lignin (ADL) were also determined in the experimental rations according to Goering and Van Soest (1970). Hemicellulose was calculated as the difference between NDF and ADF, while cellulose was calculated as the difference between ADF and ADL.

Gross energy (mega calories per kilogram DM) was calculated according to Blaxter (1968), where, each g of crude protein $(\mathrm{CP})=5.65 \mathrm{kcal}$, each $\mathrm{g}$ of ether extract $(\mathrm{EE})=9.40 \mathrm{kcal}$, and each $\mathrm{g}$ crude fiber $(\mathrm{CF})$ and nitrogen-free extract (NFE) $=4.15 \mathrm{kcal}$.

Digestible energy (DE) was calculated according to Fekete and Gippert (1986) using the following equation: DE $(\mathrm{kcal} / \mathrm{kg} \mathrm{DM})=4253-32.6(\mathrm{CF} \%)-144.4($ total ash $)$.

Non fibrous carbohydrates (NFC) were calculated according to Calsamiglia et al. (1995) using the following equation: $\mathrm{NFC}=100-\{\mathrm{CP}+\mathrm{EE}+\mathrm{Ash}+\mathrm{NDF}\}$. Diets were offered pelleted and diameter of the pellets was 4 $\mathrm{mm}$. Economical efficiency of experimental diets was calculated according to the local market price of ingredients and rabbit live body weight as following: Net revenue $=$ total revenue - total feed cost. Economical efficiency $(\%)=$ net revenue/ total feed cost $\%$.

Collected data were subjected to statistical analysis as two factors-factorial analysis of variance using the general linear model procedure of SPSS (1998). Duncan's Multiple Range Test (1955) was used to separate means when the dietary treatment effect was significant.

\section{Results and discussion}

\subsection{Chemical analysis and cell wall constituents of the experimental diets}

Digestible energy for the four tested rations $\left(\mathrm{G}_{1}-\mathrm{G}_{4}\right)$ was $2.507,2.503,2.251$ and 2.253 (Mcal/ $\mathrm{kg} \mathrm{DM}$ ), respectively (Table 2). These variations were related to differ in ingredients that used in ration formulations. The $90 \%$ of energy level containing diets showed slightly increase in NDF, and hemicellulose contents, while ADF, cellulose and non fibrous carbohydrates (NFC) contents were slightly decreased compared to control diet with $100 \%$ energy requirements. As well as ADL content of experimental rations showed approximately the same trend (Table 2). These results suggest that alterations in metabolism involved in adaptation to a diet high in hemicellulose may indicating an increased propensity for oxidative metabolism occurred in the intestine, similar result observed by Weber et al., (2010).

\subsection{Nutrient digestibility and nutritive values of the experimental diets}

Decreasing energy requirements level by $10 \%$ in rabbit diets significantly increased $(\mathrm{P}<0.05)$ the digestibility coefficients of DM, OM, CP, NFE and DCP value (Table 3). The 90\% energy level slightly increased $(\mathrm{P}<0.05)$ $\mathrm{CF}$ and EE digestibility coefficients and TDN value. The significant results may be due to that the rabbits received the low energy requirements, shift must have different digestive efficiencies for diets that correspond to its diet shift, so that nutrient and energy extraction are maximized, similar results observed by Durtsche (2004). Adding mixture of medicinal plants at $1.5 \%$ showed insignificantly $(\mathrm{P}>0.05)$ improved all nutrient digestibility coefficients and nutritive values (Table 3). These results may be due to that lupin can supply rapidly degradable protein for microbial protein synthesis and contribute to the pool of amino acids available for the synthesis and retention in the body, similar result noticed in cow by Boguhn et al. (2008). Or may be due to that fenugreek has been used for numerous indications, including aiding digestion, and as a general tonic to improve metabolism and health as observed by Basch et al. (2003) and Chevassus et al. (2010).On the other hand may be due to that senna have a marked choleretic effect and helps improve the condition of digestion (Zhu et al., 1997).

The $90 \%$ energy requirement with $1.5 \%$ additives mixture $\left(\mathrm{G}_{4}\right)$ recorded the best digestibility coefficients of DM, OM, CP, CF, EE, NFE and nutritive values of TDN and DCP (Table 4). This best digestibility coefficients values at the $90 \%$ energy requirement may be due to the ability of rabbit to maximize the extraction nutrient and energy. At the same time these results may be due to the relatively high water-binding capacity and viscosity of lupin may elicit more beneficial physiological effects in the upper gastrointestinal tract, similar result in human observed by Turnbull et al. (2005). Also, may be due to trigonelline effect of fenugreek that showed a middle 
rate of absorption and fast rate of elimination in rabbit with a good reproducibility, similar result obtained by Zhao et al. (2003). On the other hand may be due to the ability of Cassia senna L. when converted in the large intestine by gut bacteria to the active metabolite, rheinanthrone, which increases colonic motility and fluid secretion (Vanderperren et al., 2005).

There were significant $(\mathrm{P}<0.05)$ interactions between the energy and additives mixture levels on DM digestibility coefficient and DCP value, while there were no interactions between the energy and additives mixture levels on the other digestibility coefficients OM, CF, EE, NFE and TDN value (Table 4).These results in agreement with those obtained by Gross et al. (1976) who noticed that sweet lupine has been digestible without complications in all cases.

\subsection{Growth performance of the experimental groups}

The $90 \%$ energy level slightly improved $(\mathrm{P}>0.05)$ the final body weight, total weight gain and ADG $(\mathrm{g})$ compared to control 100\% energy level (Table 5). The 90\% energy level significantly $(\mathrm{P}<0.05)$ decreased feed intake as DM, CP, TDN (g/ day) and DE (kcal/head/day), while insignificantly $(\mathrm{P}>.0 .05)$ decreased $\mathrm{DCP}$ intake (g/ day) (Table 5). The $90 \%$ energy level significantly $(\mathrm{P}<0.05)$ improved feed conversion ( $\mathrm{g}$ intake/ $\mathrm{g}$ gain) of DM, CP, DCP, TDN and DE, respectively compared to control (Table 5). These results suggested that if the animal with an ontogenetic or low energy diet shift must have different digestive efficiencies for foods that correspond to its diet shift, so that nutrient and energy extraction is maximized, as explained by Durtsche (2004).

Adding mixture at $1.5 \%$ level slightly decreased $(\mathrm{P}<0.05) \mathrm{DM}, \mathrm{CP}$ and $\mathrm{DE}$ intakes, while insignificantly $(\mathrm{P}>0.05)$ decreased the DCP and TDN intakes compared to control (Table 5). This result may suggest that the use of sweet lupin seed meal in diets for growing rabbits might enhance the growth of lactic acid fermenting bacteria in the gut, similar result in brioler observed by Rubio et al. (1998). However adding mixture at $1.5 \%$ level slightly improved $(\mathrm{P}>0.05)$ final weight, total body weight gain and ADG $(\mathrm{g})$.

Adding mixture at $1.5 \%$ level significantly $(\mathrm{P}<0.05)$ improved feed conversion ( $\mathrm{g}$ intake $/ \mathrm{g}$ gain) of $\mathrm{DM}, \mathrm{CP}$, DCP, TDN and DE, respectively compared to control (Table 5). These results may be due to that the amino acids from lupin globulins proteins are probably absorbed at rates lower than in other proteins of animal origin such as casein (Rubio and Seiquer 2002), Also, may be due to the high bioaccessibility of beta-carotene from fenugreek (Veda et al., 2006). On the other hand, may due to the effect of Senna (Cassia senna L.) for enhanced permeability of disruption of tight junctions between colonic epithelial cells (Soyuncu et al., 2008).

There were no interactions between energy and additives mixture levels on rabbit performance (Table 6). The $90 \%$ energy with $1.5 \%$ additives mixture $\left(\mathrm{G}_{4}\right)$ recorded the best values of final body weight, body weight gain, and average daily gain as well as feed conversion. These best values may be due to the high palatability of lupin as observed in human by Hall et al. (2005). Or may be due to understanding the nutritional chemistry of lupin (Lupinus spp.) seed to improve livestock production efficiency (Van Barneveld 1999). On the other hand may be due to the or may due to the treating metabolic and nutritive dysfunctions effect of fenugreek seeds, as observed by Chevassus et al. (2010).

\subsection{Carcass characteristics of the experimental groups}

Energy level had insignificant ( $\mathrm{P}>0.05$ ) effect on total inedible offal's (weight and \% of SW); total edible offal's weight, carcass weight; carcass cuts and chemical analysis of CP, EE and ash contents of the 9,10 and $11^{\text {th }}$ ribs (Table 7). Supplementation additives mixture at $1.5 \%$ level significantly $(\mathrm{P}<0.05)$ increased the total inedible offal's (weight and \% of SW); and DM content 9,10 and $11^{\text {th }}$ ribs. While it had no significant effect $(\mathrm{P}>0.05)$ on total inedible offal's, carcass weight; dressing percentages carcass cuts, and CP, EE and ash contents of the 9, 10 and $11^{\text {th }}$ ribs (Table 7). These results may be due to that lupin seeds diet affected the fatty acid profile of rabbit hind leg meat and perirenal fat in a favourable manner (Volek and Marounek, 2011). On the other hand these results may be due to the beneficial effect of fenugreek as dyslipidemia, similar result in diabetic rats observed by Hannan et al. (2003); Kassaian et al. (2009) and Uemura et al. (2011).

There were no interaction between energy and additives mixture levels on total inedible offal's (weight and \% of SW); empty body weight (EBW); carcass weight and carcass cuts. While there were interactions between energy and additives mixture level on digestive tract; total edible offal's (weight and \% of SW); dressing percentages and DM \& ash contents of the 9,10 and $11^{\text {th }}$ ribs (Table 8). Also, the $90 \%$ energy and $1.5 \%$ additives mixture containing diet $\left(\mathrm{G}_{4}\right)$ recorded the best values of carcass weight including edible offal's $\left(\mathrm{CW}_{2}\right)$ (Table 8). These results may be due to that Lupin resulting in moderate changes in both protein and fibre intakes can benefit body weight and composition or blood lipids, glucose and insulin concentrations in overweight with mildly elevated cholesterol concentrations as reported by Hodgson et al. (2010). Or may be due to the purified fenugreek seeds seems to decrease lipid content as showed by Moorthy et al., (2010) and Chevassus et al. (2010). 


\subsection{Economical evaluation}

The profitability of using additives mixture depends upon the price of tested diets and the growth performance of rabbits fed these diets (Table 9). The cost of one kg feed, (LE) was decreased by $10.88 \%$ and $5.49 \% \%$ in $\mathrm{G}_{3}$ and $\mathrm{G}_{4}$, respectively compared to control diet $\mathrm{G}_{1}$. This result was due to the lowered energy level by $10 \%$ as quantity which under this study was considered the expensive components in diet.

The $90 \%$ energy requirements with or without additives mixture showed the high values of net revenue, economical efficiency and relative economic efficiency as well as the low value of feed cost/ $\mathrm{kg}$ live body weight (LE). This high values was due to the ability of additives mixture in raising the ration value by improving the utilization of low energy diet as our hypothesis via enhancing pancreatic insulin sensitivity.

The $90 \%$ energy level with $1.5 \%$ additives mixture $\left(\mathrm{G}_{4}\right)$ diet recorded the highest value of relative economic efficiency (145.1\%) and the lowest value of feed cost/ $\mathrm{kg}$ live body weight $(3.97 \mathrm{LE})$. These results are in agreement with those obtained by Ibrahim et al. (2009) who fed rabbits on two different levels of energy supplemented with herbs mixture of Artemisia herba-alba, Matricaria recutita L. and Chrysanthemum coronarium.

\section{Conclusion}

Under this conditions of this study it can be concluded that lowering the dietary energy level in rabbit diets from $100 \%$ to $90 \%$ of requirements with adding $1.5 \%$ medicinal mixture of (Lupinus albus L, Trigonella foenum-graecum L and Cassia senna L.) as feed additives improved nutrient digestibility coefficients and nutritive values as well as realized the highest value of relative economic efficiency and lowered value of feed cost/ $\mathrm{kg}$ live body weight. Also, our data suggest that this mixture of medicinal plants can be considered as growth promoter that is effective for improving the utilization of low energy diet by lowering circulating glucose levels through enhancing insulin sensitivity.

\section{References}

A.O.A.C. (2000). Official Methods of Analysis, $17^{\text {th }}$ ed. Association of Official Analytical Chemists, Washington, D.C, USA.

Basch, E., Ulbricht, C., Kuo, G., Szapary, P. \& Smith M. (2003). Therapeutic applications of fenugreek. Altern Med Rev., Feb, 8(1):20-27.

Bisset, NG., Herbal, Drugs \& Phytopharmaceuticals. (1994). Stuttgart, Germany: Medpharm Scientific Publishers and Boca Raton, FL: CRC Press Inc.

Blasco, A., Quhayaun, J. \& Masoscro, G. (1993). Hormonization of criteria and terminology in rabbit meat research. World Rabbits Sciences, 1: 3-10.

Blaxter, K.L. (1968). The energy metabolism of ruminants. $2^{\text {nd }}$ ed. Charles Thomas Publisher. Spring field. Illinois, U.S.A.

Boguhn, J., Kluth, H., Bulang, M., Engelhard, T., Spilke, J. \& Rodehutscord, M. (2008). Effects of using thermally treated lupins instead of soybean meal and rapeseed meal in total mixed rations on in vitro microbial yield and performance of dairy cows. J Anim hysiol. Anim. Nutr., (Berl). Dec, 92(6):694-704.

Calsamiglia, S., Stem, M.D. \& Frinkins, J.L. (1995). Effects of protein source on nitrogen metabolism in continuous culture and intestinal digestion in vitro. J. Anim. Sci., 73:1819.

Chevassus, H., Gaillard, JB., Farret, A., Costa, F., Gabillaud, I., Mas, E., Dupuy, AM., Michel, F., Cantié, C., Renard, E., Galtier, F. \& Petit, P. (2010). A fenugreek seed extract selectively reduces spontaneous fat intake in overweight subjects. Eur. J. Clin. Pharmacol., May, 66(5):449-55.

Duncan, D.B. (1955). Multiple Rang and Multiple F-Test Biometrics, 11: 1-42. http://dx.doi.org/10.2307/3001478

Durtsche, R.D. (2004). Ontogenetic variation in digestion by the herbivorous lizard Ctenosaura pectinata. Physiol. Biochem. Zool., May-Jun, 77(3):459-470.

Fekete, S. \& Gippert, T. (1986). Digestibility and nutritive value of nineteen important feedstuffs for rabbits. $J$. Appli. Rabbit Res., 9 (3): 103-108.

Goering, H. K. \& Van Soest, P.J. (1970). Forge fiber analysis (apparatus, reagents, procedure and some applications). Agric. Hand book, 379, USDA, Washington, and DC., USA.

Gross, R., Morales, E., Gross, U. \& Von Baer, E. (1976). Lupine, a contribution to the human food supply. 3. Nutritional physiological study with lupine (Lupinus albus) flour. Z. Ernahrungswiss. Dec, 15(4):391-395. 
Hall, RS., Johnson, SK., Baxter, AL. \& Ball, MJ. (2005). Lupin kernel fiber-enriched foods beneficially modify serum lipids in men. Eur. J. Clin .Nutr., Mar, 59(3):325-333.

Hannan, JM., Ali, L., Rokeya, B., Khaleque, J., Akhter, M., Flatt, PR. \& Abdel-Wahab, YH. (2007). Soluble dietary fiber fraction of Trigonella foenum-graecum (fenugreek) seed improves glucose homeostasis in animal models of type 1 and type 2 diabetes by delaying carbohydrate digestion and absorption, and enhancing insulin action. Br J Nutr., Mar, 97(3):514-21.

Hannan, JM., Rokeya, B., Faruque, O., Nahar, N., Mosihuzzaman, M., Azad Khan, AK. \& Ali, L. (2003). Effect of soluble dietary fiber fraction of Trigonella foenum graecum on glycemic, insulinemic, lipidemic and platelet aggregation status of Type 2 diabetic model rats. J. Ethnopharmacol., Sep, 88(1):73-77.

Hodgson, JM., Lee, YP., Puddey, IB., Sipsas, S., Ackland, TR., Beilin, LJ., Belski, R. \& Mori, TA. (2010). Effects of increasing dietary protein and fiber intake with lupin on body weight and composition and blood lipids in overweight men and women. Int. J. Obes., (Lond). Jun, 34(6):1086-1094.

Hughes, RJ., Choct, M., Kocher, A. \& Van Barneveld, RJ. (2000). Effect of food enzymes on AME and composition of digesta from broiler chickens fed on diets containing non-starch polysaccharides isolated from lupin kernel. Br. Poult. Sci., Jul, 41(3):318-323.

Ibrahim, Sh. A. M., Abedo, A.A., Omer, H.A.A. \& Ali, F.A.F. (2009). Response of growing New Zealand White rabbits to diets containing different levels of energy and mixture of some medical plants. World Journal of Agricultural Science, 5 (5): 544-551.

Kassaian, N., Azadbakht, L., Forghani, B. \& Amini, M. (2009). Effect of fenugreek seeds on blood glucose and lipid profiles in type 2 diabetic patients. Int. J. Vitam. Nutr. Res., Jan, 79(1):34-39.

Lee, YP., Mori, TA., Sipsas, S., Barden, A., Puddey, IB., Burke, V., Hall, RS. \& Hodgson, JM. (2006). Lupin-enriched bread increases satiety and reduces energy intake acutely. Am. J. Clin. Nutr., Nov, 84(5):975-980.

Mathern, JR., Raatz, SK., Thomas, W. \& Slavin, JL. (2009). Effect of fenugreek fiber on satiety, blood glucose and insulin response and energy intake in obese subjects. Phytother Res., Nov, 23(11):1543-1548.

Moorthy, R., Prabhu, KM. \& Murthy, PS. (2010). Anti-hyperglycemic compound (GII) from fenugreek (Trigonella foenum-graecum Linn.) seeds, its purification and effect in diabetes mellitus. Indian J. Exp. Biol., Nov, 48(11):1111-1118.

Müllera, P. \& Basedow, T. 1.A. (2006). Aflatoxin contamination of pods of Indian Cassia senna L. (Caesalpinaceae) before harvest, during drying and in storage: Reasons and possible methods of reduction. Journal of Stored Products Research, Volume 43, Issue 4, Pages 323-329.

N.R.C. (1977). National Research Council. Nutrient requirements of rabbits, National Academy of Science, Washington, D.C, USA.

Nadal. SR., Calore, EE., Manzione, CR., Puga, FR. \& Perez, NM. (2003). Effects of long-term administration of Senna occidentalis seeds in the large bowel of rats. Pathol. Res. Pract., 199(11):733-737. http://dx.doi.org/10.1078/0344-0338-00489

Newall, CA., Anderson, LA., Phillipson, JD. (1996). Herbal Medicines. A Guide for Health-Care Professionals. London, England: The Pharmaceutical Press, 243-244.

O'Mary, C.C., Everett, L.M. \& Graig, A.D. (1979). Production and carcass characteristics of Angus and Charolais x Angus steers. J. Anim. Sci., 48: 239.

Porres, JM., Aranda, P., López-Jurado, M. \& Urbano, G. (2006). Nutritional evaluation of protein, phosphorus, calcium and magnesium bioavailability from lupin (Lupinus albus var. multolupa)-based diets in growing rats: effect of alpha-galactoside oligosaccharide extraction and phytase supplementation. Br. J. Nutr., Jun, 95 (6): 1102-1111.

Raju, J., Patlolla, JM., Swamy, MV. \& Rao, CV. (2004). Diosgenin, a steroid saponin of Trigonella foenum graecum (Fenugreek), inhibits azoxymethane-induced aberrant crypt foci formation in F344 rats and induces apoptosis in HT-29 human colon cancer cells. Cancer Epidemiol Biomarkers Prev., Aug, 13 (8): 1392-1398.

Rubio LA, Brenes A, Setién I, de la Asunción G, Durán N, Cutuli MT. (1998). Lactobacilli counts in crop, ileum and caecum of growing broiler chickens fed on practical diets containing whole or dehulled sweet lupin (Lupinus angustifolius) seed meal. Br Poult Sci., Jul, 39(3):354-9.

Rubio, LA. \& Seiquer, I. (2002). Transport of amino acids from in vitro digested legume proteins or casein in Caco-2 cell cultures. J. Agric. Food Chem., Aug 28, 50 (18): 5202-5206. 
Sami, AS., Schuster, M. \& Schwarz, FJ. (2010). Performance, carcass characteristics and chemical composition of beef affected by lupine seed rapeseed meal and soybean meal. J. Anim. Physiol. Anim. Nutr., (Berl). Aug 1, 94 (4): 465-473.

Soyuncu, S., Cete, Y. \& Nokay, AE. (2008). Portal vein thrombosis related to Cassia angustifolia . Clin. Toxicol., (Phila). 46 (8): 774-777.

SPSS. (1998). Statistical package for Social Sciences, Chicago, U.S.A.

Talpur, N., Echard, B, Ingram, C, Bagchi, D. \& Preuss, H. (2005). Effect of a novel formulation of essential oils on glucose-insulin metabolism in diabetic and hypertensive rats: a pilot study. Diabetes Obes. Metab., 3, 7 (2): 193-199.

Turnbull, CM., Baxter, AL. \& Johnson, SK. (2005). Water-binding capacity and viscosity of Australian sweet lupin kernel fiber under in vitro conditions simulating the human upper gastrointestinal tract. Nut. J. Food Sci., Nut Mar, 56 (2): 87-94.

Uemura, T., Goto, T., Kang, MS., Mizoguchi, N., Hirai, S., Lee, JY., Nakano, Y., Shono, J., Hoshino, S., Taketani, K., Tsuge, N., Narukami, T., Makishima, M., Takahashi, N. \& Kawada, T. (2011). Diosgenin, the main aglycon of fenugreek, inhibits LXRa activity in HepG2 cells and decreases plasma and hepatic triglycerides in obese diabetic mice. $J$ Nutr., Jan, 141(1):17-23.

Van Barneveld, RJ. (1999). Understanding the nutritional chemistry of lupin (Lupinus spp.) seed to improve livestock production efficiency. Nutr. Res. Rev., $12 \quad$ (2): 203-230. http://dx.doi.org/10.1079/095442299108728938

Vanderperren, B., Rizzo, M., Angenot, L., Haufroid, V., Jadoul, M. \& Hantson, P. (2005). Acute liver failure with renal impairment related to the abuse of senna anthraquinone glycosides. Ann. Pharmacother., 39 (7-8): 1353-1357. http://dx.doi.org/10.1345/aph.1E670

Veda, S., Kamath, A., Platel, K., Begum, K. \& Srinivasan, K. (2006). Determination of bioaccessibility of beta-carotene in vegetables by in vitro methods. Mol. Nutr. Food. Res., Nov, 50 (11): 1047-1052.

Volek, Z. \& Marounek, M. (2011). Effect of feeding growing-fattening rabbits a diet supplemented with whole white lupin (Lupinus albus cv. Amiga) seeds on fatty acid composition and indexes related to human health in hind leg meat and perirenal fat. Meat Sci., Jan, 87 (1): 40-45.

Weber, TE., Trabue, SL., Ziemer, CJ. \& Kerr, BJ. (2010). Evaluation of elevated dietary corn fiber from corn germ meal in growing female pigs. J. Anim. Sci., Jan, 88 (1): 192-201.

Zhao, HQ., Qu, Y., Wang, XY., Lu, XY., Zhang, XH. \& Hattori, M. (2003). Determination of trigonelline by HPLC and study on its pharmacokinetics. Article in Chinese. Yao Xue Xue Bao. Apr, 38 (4): $279-282$.

Zhu, Z., Zhang, M., Shen, Y. \& Wang, H. (1997). Pharmacological effect of cortex Magnoliae officinalis on digestion system]. Zhongguo Zhong Yao Za Zhi. Nov, 22 (11): 686-688.

Table 1. Composition of the experimental diets ( $\mathrm{kg} / \mathrm{ton})$

\begin{tabular}{|l|c|c|c|c|}
\hline \multirow{2}{*}{ Item } & \multicolumn{2}{|c|}{$100 \%$} & \multicolumn{2}{c|}{$90 \%$} \\
& \multicolumn{2}{|c|}{ Energy requirements } & \multicolumn{2}{c|}{ Energy requirements } \\
\cline { 2 - 5 } & $\mathrm{G}_{1}$ & $\mathrm{G}_{2}$ & $\mathrm{G}_{3}$ & $\mathrm{G}_{4}$ \\
\hline Yellow corn & 220 & 220 & --- & ---- \\
Barley grain & 60 & 60 & 150 & 150 \\
Wheat bran & 270 & 270 & 270 & 270 \\
Soybean meal 44\% CP & 150 & 150 & 150 & 150 \\
Alfalfa hay & 270 & 255 & 260 & 260 \\
Clover straw & --- & ---- & 140 & 125 \\
Di- Ca- Phosphate & 10 & 10 & 10 & 10 \\
Lime stone & 10 & 10 & 10 & 10 \\
Sodium chloride & 5 & 5 & 5 & 3 \\
Vit. \& Min. mixture* & 3 & 3 & 3 & 1 \\
Anti fungal agent & 1 & 1 & 1 & 1 \\
DL-Methionine & 1 & 1 & 1 & 15 \\
Plants mixture supplement & --- & 15 & --- & 1981 \\
\hline Price, L.E/Ton & 2096 & 2191 & 1868 & 3 \\
\hline
\end{tabular}

* Vit. \& Min. mixture: Each kilogram of Vit. \& Min. mixture contains: 2000.000 IU Vit. A, 150.000 IU Vita. D, 8.33 g Vit. E, 0.33 g Vit. K, 0.33 g Vit. $B_{1}, 1.0$ g Vit. $B_{2}, 0.33$ g Vit. $B_{6}, 8.33$ g Vit. $B_{5}, 1.7$ mg Vit. B $12,3.33$ g Pantothenic acid, $33 \mathrm{mg}$ Biotin, 0.83g Folic acid, $200 \mathrm{~g}$ Choline chloride, $11.7 \mathrm{~g} \mathrm{Zn}, 12.5 \mathrm{~g}$ Fe, $16.6 \mathrm{mg}$ Se, 16.6 $\mathrm{mg} \mathrm{Co,} \mathrm{66.7} \mathrm{g} \mathrm{Mg}$ and $5 \mathrm{~g} \mathrm{Mn}$. 
Table 2. Chemical analysis and cell wall constituents of the experimental diets

\begin{tabular}{|l|c|c|c|c|}
\hline \multirow{2}{*}{ Item } & \multicolumn{2}{|c|}{$\begin{array}{c}100 \% \\
\text { Energy requirements }\end{array}$} & \multicolumn{2}{c|}{$\begin{array}{c}9 \% \\
\text { Energy requirements }\end{array}$} \\
\cline { 2 - 5 } & $\mathrm{G}_{1}$ & $\mathrm{G}_{2}$ & $\mathrm{G}_{3}$ & $\mathrm{G}_{4}$ \\
\hline Dry matter & 91.32 & 91.37 & 91.00 & 91.58 \\
\hline Chemical analysis on dry matter basis & 90.82 & 90.68 & 89.32 & 89.03 \\
\hline Organic matter (OM) & 14.14 & 14.18 & 14.12 & 14.16 \\
Crude protein (CP) & 12.89 & 12.40 & 12.69 & 12.76 \\
Crude fiber (CF) & 3.46 & 3.38 & 3.34 & 3.34 \\
Ether extract (EE) & 60.33 & 60.72 & 59.17 & 58.77 \\
Nitrogen-free extract (NFE) & 9.18 & 9.32 & 10.68 & 10.97 \\
Ash & 4.163 & 4.154 & 4.095 & 4.083 \\
\hline Gross energy (Mcal/ kg DM) ${ }^{1}$ & 2507 & 2503 & 2251 & 2253 \\
\hline Digestible energy (kcal/kg DM) ${ }^{2}$ & 33.53 & 34.17 & 32.33 & 32.38 \\
\hline Non fibrous carbohydrates (NFC) ${ }^{3}$ & 39.69 & 38.95 & 39.53 & 39.15 \\
\hline Cell wall constituents & 18.26 & 17.93 & 16.45 & 16.15 \\
\hline NDF & 6.46 & 6.30 & 6.86 & 6.77 \\
ADF & 21.43 & 21.02 & 23.08 & 23.00 \\
ADL & 11.80 & 11.63 & 9.59 & 9.38 \\
Hemicellulose & \multicolumn{5}{|l|}{} \\
Cellulose &
\end{tabular}

${ }^{1}$ Gross energy (mega calories per kilogram DM) was calculated according to Blaxter (1968), where, each g of crude protein $(\mathrm{CP})=5.65 \mathrm{kcal}$, each $\mathrm{g}$ of ether extract $(\mathrm{EE})=9.40 \mathrm{kcal}$, and each $\mathrm{g}$ crude fiber $(\mathrm{CF})$ and nitrogen-free extract $(\mathrm{NFE})=4.15 \mathrm{kcal}$.

${ }^{2}$ Digestible energy (DE) was calculated according to Fekete and Gippert (1986) using the following equation:

$\mathrm{DE}(\mathrm{kcal} / \mathrm{kg} \mathrm{DM})=4253-32.6(\mathrm{CF} \%)-144.4$ (total ash).

${ }^{3}$ Non fibrous carbohydrates (NFC), calculated according to Calsamiglia et al. (1995) using the following equation:

$\mathrm{NFC}=100-\{\mathrm{CP}+\mathrm{EE}+\mathrm{Ash}+\mathrm{NDF}\}$.

NDF: Neutral detergent fiber. ADF: Acid detergent fiber. ADL: Acid detergent lignin.

Hemicellulose $=\mathrm{NDF}-\mathrm{ADF}$. Cellulose $=\mathrm{ADF}-\mathrm{ADL}$.

Table 3. Main effects of energy and supplementation levels on nutrient digestibility coefficients and nutritive values of the experimental diets

\begin{tabular}{|c|c|c|c|c|c|c|}
\hline \multirow[b]{3}{*}{ Item } & \multicolumn{5}{|c|}{ Experimental diets } & \multirow[b]{3}{*}{ SEM } \\
\hline & \multicolumn{2}{|c|}{ Energy levels } & \multirow[b]{2}{*}{ SEM } & \multicolumn{2}{|c|}{ Supplementation } & \\
\hline & $100 \%$ & $90 \%$ & & $0 \%$ & $1.5 \%$ & \\
\hline \multicolumn{7}{|c|}{ Nutrient digestibility coefficients } \\
\hline Dry matter (DM) & $71.95^{\mathrm{b}}$ & $77.31^{\mathrm{a}}$ & 1.04 & 74.42 & 74.84 & 1.04 \\
\hline Organic matter $(\mathrm{OM})$ & $63.88^{\mathrm{b}}$ & $68.94^{\mathrm{a}}$ & 1.24 & 65.68 & 67.14 & 1.24 \\
\hline Crude protein $(\mathrm{CP})$ & $68.40^{\mathrm{b}}$ & $74.45^{\mathrm{a}}$ & 1.25 & 71.24 & 71.61 & 1.25 \\
\hline Crude fiber (CF) & 28.61 & 33.00 & 2.79 & 27.42 & 34.19 & 2.79 \\
\hline Ether extract (EE) & 76.68 & 78.88 & 0.99 & 77.63 & 77.92 & 0.99 \\
\hline Nitrogen-free extract (NFE) & $69.49^{\mathrm{b}}$ & $74.80^{\mathrm{a}}$ & 1.14 & 71.87 & 72.42 & 1.14 \\
\hline \multicolumn{7}{|l|}{ Nutritive values } \\
\hline TDN\% & 61.26 & 64.78 & 1.04 & 62.45 & 63.59 & 1.04 \\
\hline $\mathrm{DCP} \%$ & $9.69^{\mathrm{b}}$ & $10.53^{\mathrm{a}}$ & 0.17 & 10.07 & 10.15 & 0.17 \\
\hline
\end{tabular}

$\mathrm{a}$ and $\mathrm{b}$ : Means in the same row within each treatment having different superscripts differ significantly $(\mathrm{P}<0.05)$.

SEM, standard error of the mean.

Table 4. Effect of interactions between energy and supplementation levels on nutrient digestibility coefficients and nutritive values of the experimental diets

\begin{tabular}{|c|c|c|c|c|c|}
\hline \multirow[b]{3}{*}{ Item } & \multicolumn{5}{|c|}{ Experimental rations } \\
\hline & \multicolumn{2}{|c|}{$\begin{array}{c}100 \% \\
\text { Energy requirements }\end{array}$} & \multicolumn{2}{|c|}{$\begin{array}{c}90 \% \\
\text { Energy requirements }\end{array}$} & \multirow[b]{2}{*}{ SEM } \\
\hline & $\mathrm{G}_{1}$ & $\mathrm{G}_{2}$ & $\mathrm{G}_{3}$ & $\mathrm{G}_{4}$ & \\
\hline \multicolumn{6}{|c|}{ Nutrient digestibility coefficients } \\
\hline Dry matter (DM) & $71.92^{\mathrm{c}}$ & $71.98^{\mathrm{bc}}$ & $76.92^{\mathrm{ab}}$ & $77.69^{\mathrm{a}}$ & 1.04 \\
\hline Organic matter $(\mathrm{OM})$ & 63.55 & 64.22 & 67.80 & 70.07 & 1.24 \\
\hline Crude protein $(\mathrm{CP})$ & 68.32 & 68.48 & 74.15 & 74.74 & 1.25 \\
\hline Crude fiber (CF) & 28.82 & 28.24 & 26.05 & 39.97 & 2.79 \\
\hline Ether extract (EE) & 75.45 & 77.90 & 79.81 & 77.94 & 0.99 \\
\hline Nitrogen-free extract (NFE) & 69.17 & 69.81 & 74.57 & 75.03 & 1.14 \\
\hline \multicolumn{6}{|l|}{ Nutritive values } \\
\hline TDN\% & 60.99 & 61.52 & 63.90 & 65.65 & 1.04 \\
\hline $\mathrm{DCP} \%$ & $9.66^{\mathrm{b}}$ & $9.71^{\mathrm{ab}}$ & $10.47^{\mathrm{ab}}$ & $10.59^{\mathrm{a}}$ & 0.17 \\
\hline
\end{tabular}

$\mathrm{a}, \mathrm{b}$ and $\mathrm{c}$ : Means in the same row having different superscripts differ significantly $(\mathrm{P}<0.05)$.

SEM, standard error of the mean. 
Table 5. Main effects of energy and supplementation levels on growth performance of the experimental groups

\begin{tabular}{|c|c|c|c|c|c|c|}
\hline \multirow[b]{3}{*}{ Item } & \multicolumn{5}{|c|}{ Experimental diets } & \multirow[b]{3}{*}{ SEM } \\
\hline & \multicolumn{2}{|c|}{ Energy levels } & \multirow[b]{2}{*}{ SEM } & \multicolumn{2}{|c|}{ Supplementation } & \\
\hline & $100 \%$ & $90 \%$ & & $0 \%$ & $1.5 \%$ & \\
\hline Initial weight, $g$ & 796 & 795 & 18.19 & 794 & 797 & 18.19 \\
\hline Final weight, $g$ & 2514 & 2548 & 47.24 & 2497 & 2566 & 47.24 \\
\hline Total body weight gain, $g$ & 1718 & 1753 & 48.24 & 1703 & 1769 & 48.24 \\
\hline Duration period (days) & 56 & 56 & ---- & 56 & 56 & ---- \\
\hline Average daily gain (ADG), $g$ & 30.68 & 31.30 & 0.86 & 30.41 & 31.59 & 0.86 \\
\hline \multicolumn{7}{|l|}{ Feed intake as: } \\
\hline DM, g/head/day & $105.05^{\mathrm{a}}$ & $89.46^{\mathrm{b}}$ & 3.05 & $101.67^{\mathrm{a}}$ & $92.84^{\mathrm{b}}$ & 3.05 \\
\hline $\mathrm{CP}, \mathrm{g} /$ head/day & $13.29^{\mathrm{a}}$ & $11.38^{\mathrm{b}}$ & 0.40 & $13.01^{\mathrm{a}}$ & $11.66^{\mathrm{b}}$ & 0.40 \\
\hline DCP, g/head/day & 10.17 & 9.42 & 0.25 & 10.20 & 9.39 & 0.25 \\
\hline TDN, g/head/day & $64.34^{\mathrm{a}}$ & $57.90^{\mathrm{b}}$ & 1.61 & 63.36 & 58.88 & 1.61 \\
\hline DE, Kcal/head/day & $263^{\mathrm{a}}$ & $201^{\mathrm{b}}$ & 9.66 & $243^{\mathrm{a}}$ & $222^{\mathrm{b}}$ & 9.66 \\
\hline \multicolumn{7}{|c|}{ Feed conversion ( $\mathrm{g}$ intake /g gain) of } \\
\hline DM & $3.43^{\mathrm{a}}$ & $2.86^{\mathrm{b}}$ & 0.11 & $3.35^{\mathrm{a}}$ & $2.94^{\mathrm{b}}$ & 0.11 \\
\hline $\mathrm{CP}$ & $0.43^{\mathrm{a}}$ & $0.37^{\mathrm{b}}$ & 0.01 & $0.43^{\mathrm{a}}$ & $0.37^{\mathrm{b}}$ & 0.01 \\
\hline DCP & $0.33^{\mathrm{a}}$ & $0.30^{\mathrm{b}}$ & 0.01 & $0.34^{\mathrm{a}}$ & $0.30^{\mathrm{b}}$ & 0.01 \\
\hline TDN & $2.10^{\mathrm{a}}$ & $1.85^{\mathrm{b}}$ & 0.06 & $2.08^{\mathrm{a}}$ & $1.86^{\mathrm{b}}$ & 0.06 \\
\hline DE (Kcal intake /g gain) & $8.59^{\mathrm{a}}$ & $6.45^{\mathrm{b}}$ & 0.34 & $8.00^{\mathrm{a}}$ & $7.05^{\mathrm{b}}$ & 0.34 \\
\hline
\end{tabular}

$\mathrm{a}$ and $\mathrm{b}$ : Means in the same row within each treatment having different superscripts differ significantly $(\mathrm{P}<0.05)$.

SEM, standard error of the mean.

Table 6. Effect of interactions between energy and supplementation levels on growth performance of the experimental groups

\begin{tabular}{|c|c|c|c|c|c|}
\hline \multirow[b]{3}{*}{ Item } & \multicolumn{5}{|c|}{ Experimental rations } \\
\hline & \multicolumn{2}{|c|}{$\begin{array}{c}100 \% \\
\text { Energy requirements }\end{array}$} & \multicolumn{2}{|c|}{$\begin{array}{c}90 \% \\
\text { Energy requirements }\end{array}$} & \multirow[b]{2}{*}{ SEM } \\
\hline & $\mathrm{G}_{1}$ & $\mathrm{G}_{2}$ & $\mathrm{G}_{3}$ & $\mathrm{G}_{4}$ & \\
\hline Initial weight, $\mathrm{g}$ & 797 & 795 & 791 & 799 & 18.19 \\
\hline Final weight, $\mathrm{g}$ & 2497 & 2532 & 2496 & 2601 & 47.24 \\
\hline Total body weight gain, $g$ & 1700 & 1737 & 1705 & 1802 & 48.24 \\
\hline Duration period (days) & 56 & 56 & 56 & 56 & --- \\
\hline Average daily gain (ADG), $\mathrm{g}$ & 30.36 & 31.02 & 30.45 & 32.18 & 0.86 \\
\hline \multicolumn{6}{|l|}{ Feed intake as: } \\
\hline DM, g/head/day & $109.6^{\mathrm{a}}$ & $100.5^{\mathrm{ab}}$ & $93.70^{\mathrm{bc}}$ & $85.00^{\mathrm{c}}$ & 3.05 \\
\hline CP, g/head/day & $14.13^{\mathrm{a}}$ & $12.46^{\mathrm{ab}}$ & $11.89^{\mathrm{b}}$ & $10.87^{\mathrm{b}}$ & 0.40 \\
\hline DCP, g/head/day & $10.59^{\mathrm{a}}$ & $9.76^{\mathrm{ab}}$ & $9.81^{\mathrm{ab}}$ & $9.02^{\mathrm{b}}$ & 0.25 \\
\hline TDN, g/head/day & $66.85^{\mathrm{a}}$ & $61.83^{\mathrm{ab}}$ & $59.87^{\mathrm{ab}}$ & $55.93^{\mathrm{b}}$ & 1.61 \\
\hline DE, Kcal/head/day & $275^{\mathrm{a}}$ & $252^{\mathrm{a}}$ & $211^{\mathrm{b}}$ & $192^{b}$ & 9.66 \\
\hline \multicolumn{6}{|c|}{ Feed conversion ( $\mathrm{g}$ intake /g gain) of } \\
\hline $\mathrm{DM}$ & $3.61^{\mathrm{c}}$ & $3.24^{\mathrm{bc}}$ & $3.08^{\mathrm{ab}}$ & $2.65^{\mathrm{a}}$ & 0.11 \\
\hline $\mathrm{CP}$ & $0.47^{\mathrm{c}}$ & $0.40^{\mathrm{b}}$ & $0.39^{\mathrm{ab}}$ & $0.34^{\mathrm{a}}$ & 0.01 \\
\hline $\mathrm{DCP}$ & $0.35^{\mathrm{b}}$ & $0.31^{\mathrm{ab}}$ & $0.32^{\mathrm{ab}}$ & $0.28^{\mathrm{a}}$ & 0.01 \\
\hline TDN & $2.20^{\mathrm{b}}$ & $1.99^{\mathrm{ab}}$ & $1.97^{\mathrm{ab}}$ & $1.74^{\mathrm{a}}$ & 0.06 \\
\hline DE (Kcal intake /g gain) & $9.06^{\mathrm{b}}$ & $8.12^{\mathrm{b}}$ & $6.93^{\mathrm{a}}$ & $5.97^{\mathrm{a}}$ & 0.34 \\
\hline
\end{tabular}

$\mathrm{a}, \mathrm{b}$ and $\mathrm{c}$ : Means in the same row having different superscripts differ significantly $(\mathrm{P}<0.05)$.

SEM, standard error of the mean. 
Table 7. Main effects of energy and supplementation levels on carcass characteristics of the experimental groups

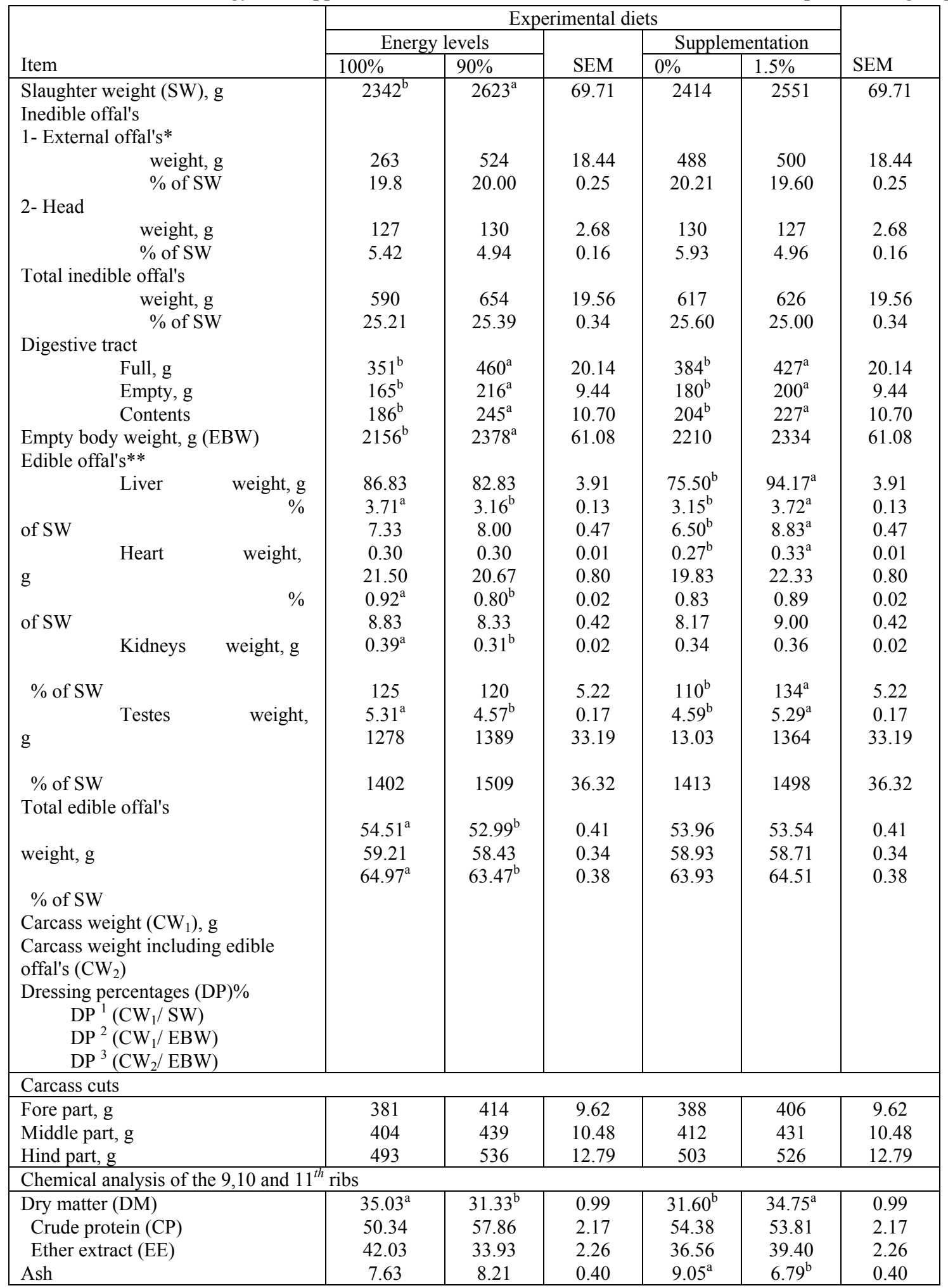

$a$ and $b$ : Means in the same row within each treatment having different superscripts differ significantly $(\mathrm{P}<0.05)$.

SEM, standard error of the mean.

* External offal's: included Fur, ears, legs and blood. **Edible offal's: included liver, heart, kidneys and testes.

Empty body weight $(\mathrm{EBW})=$ slaughter weight - digestive tract contents . 
Table 8. Effect of interactions between energy and supplementation levels on carcass characteristics of the experimental groups

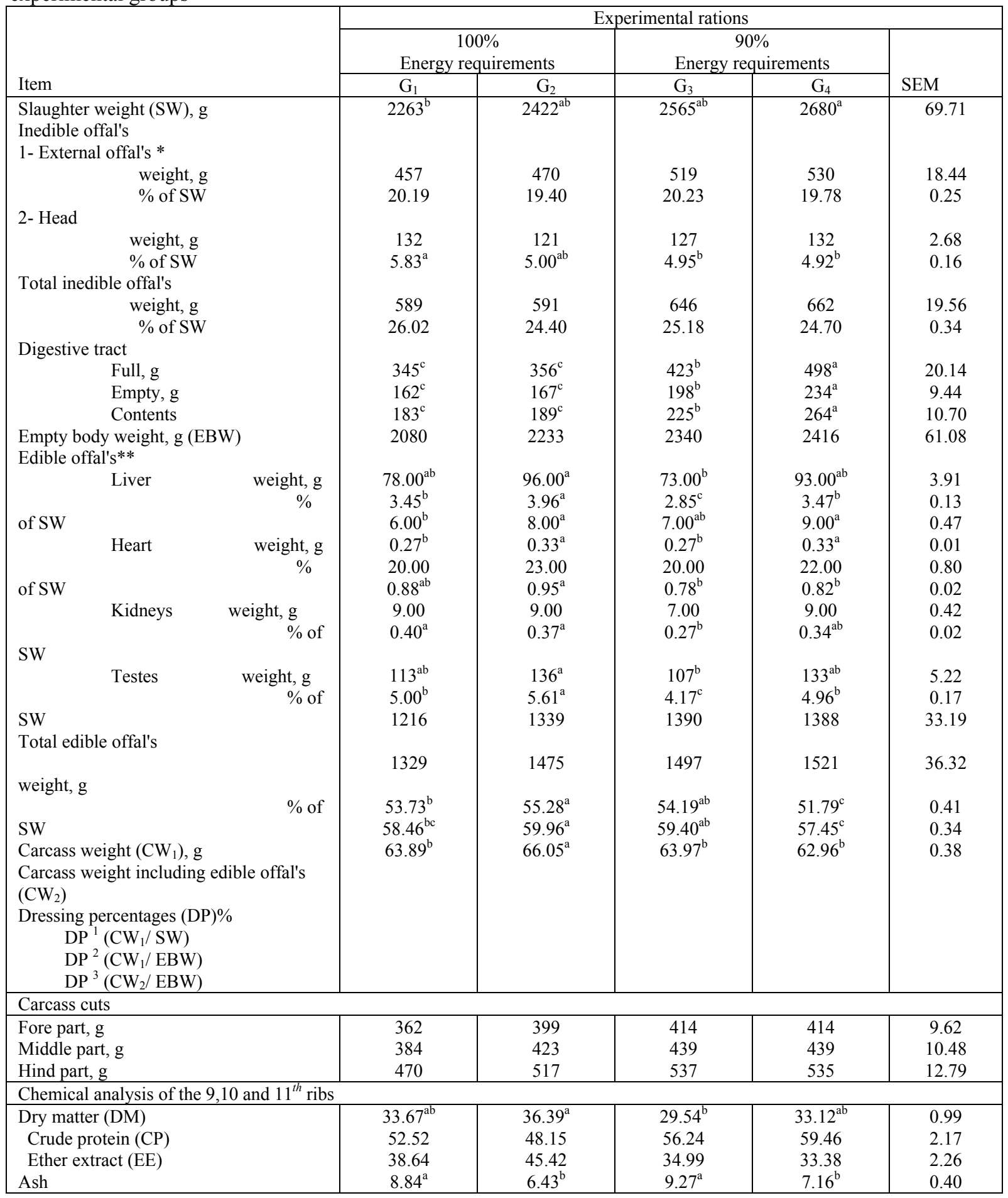

$\mathrm{a}, \mathrm{b}$ and $\mathrm{c}$ : Means in the same row having different superscripts differ significantly $(\mathrm{P}<0.05)$.

SEM, standard error of the mean.

* External offal's: included Fur, ears, legs and blood.

** Edible offal's: included liver, heart, kidneys and testes.

Empty body weight $(\mathrm{EBW})=$ slaughter weight - digestive tract contents. 
Table 9. Economical evaluation of the experimental groups

\begin{tabular}{|c|c|c|c|c|}
\hline \multirow[b]{3}{*}{ Item } & \multicolumn{4}{|c|}{ Experimental rations } \\
\hline & \multicolumn{2}{|c|}{$\begin{array}{c}100 \% \\
\text { Energy requirements }\end{array}$} & \multicolumn{2}{|c|}{$\begin{array}{l}90 \% \\
\text { Energy requirements }\end{array}$} \\
\hline & $\mathrm{G}_{1}$ & $\mathrm{G}_{2}$ & $\mathrm{G}_{3}$ & $\mathrm{G}_{4}$ \\
\hline Marketing weight, $\mathrm{Kg}$ & 2.497 & 2.532 & 2.496 & 2.601 \\
\hline Feed consumed / rabbit, kg & 6.720 & 6.160 & 5.768 & 5.208 \\
\hline Costing of one $\mathrm{kg}$ feed, $(\mathrm{LE})^{1}$ & 2.096 & 2.191 & 1.868 & 1.981 \\
\hline Total feed cost, (LE) & 14.09 & 13.50 & 10.77 & 10.32 \\
\hline Management/ Rabbit, (LE) ${ }^{2}$ & 4 & 4 & 4 & 4 \\
\hline Total cost, $(\mathrm{LE})^{3}$ & 34.09 & 33.50 & 30.77 & 30.32 \\
\hline Total revenue, $(\mathrm{LE})^{4}$ & 54.93 & 55.70 & 54.91 & 57.22 \\
\hline Net revenue & 20.84 & 22.20 & 24.14 & 26.90 \\
\hline Economical efficiency ${ }^{5}$ & 0.6113 & 0.6627 & 0.7845 & 0.8872 \\
\hline Relative economic efficiency ${ }^{6}$ & 100 & 108.4 & 128.3 & 145.1 \\
\hline Feed cost $/ \mathrm{kg} \mathrm{LBW}(\mathrm{LE})^{7}$ & 5.64 & 5.33 & 4.31 & 3.97 \\
\hline
\end{tabular}

${ }^{1}$ Based on prices of year 2010.

${ }^{2}$ Include medication, vaccines, sanitation and workers.

${ }^{3}$ include the feed cost of experimental rabbit which was LE 16/ rabbit + management.

${ }^{4}$ Body weight $\mathrm{x}$ price of one $\mathrm{kg}$ at selling which was LE 22.

${ }^{5}$ net revenue per unit of total cost.

${ }^{6}$ Assuming that the relative economic efficiency of control diet equal 100 .

${ }^{7}$ Feed cost $/ \mathrm{kg} \mathrm{LBW}=$ feed intake $*$ price of $\mathrm{kg} /$ Live weight. 